Annals of Warsaw University of Life Sciences - SGGW

Land Reclamation No 49 (2), 2017: 107-116

(Ann. Warsaw Univ. of Life Sci. - SGGW, Land Reclam. 49 (2), 2017)

\title{
Determination of undrained shear strength and constrained modulus from DMT for stiff overconsolidated clays
}

\author{
ZBIGNIEW LECHOWICZ ${ }^{1}$, SIMON RABARIJOELY ${ }^{1}$, TETIANA KUTIA ${ }^{2}$ \\ ${ }^{1}$ Faculty of Civil and Environmental Engineering, Warsaw University of Life Sciences - SGGW \\ ${ }^{2}$ Department of Applied Mathematics, National University of Water and Environmental Engineering, \\ Ukraine
}

\begin{abstract}
Determination of undrained shear strength and constrained modulus from DMT for stiff overconsolidated clays. The paper presents the results of dilatometer and laboratory tests performed on heavily preconsolidated boulder clays and Pliocene clays prevailing in the Warsaw region. Several different correlations available for evaluating undrained shear strength and constrained modulus from dilatometer tests are discussed. Empirical coefficients for multi-factor correlation to obtain undrained shear strength from dilatometer tests for boulder clays and Pliocene clays were determined. The relationship between factor $R_{M}$ and horizontal stress index $\left(K_{D}\right)$ for boulder clays was proposed for the evaluation of constrained modulus from dilatometer tests.
\end{abstract}

Key words: cohesive soils, undrained shear strength, constrained modulus, dilatometer test

\section{INTRODUCTION}

The Flat Dilatometer (DMT) was developed in Italy by Silvano Marchetti in 1980 for establishing test methods and original correlations for the evaluation of selected geotechnical parameters. As a load-displacement test, DMT provides very good information on stress history, stiffness and shear strength of soils. It is standardized in Eurocode 7 (1997, 2007) and ASTM (D6635-01 2001, 2007). Detailed information on the DMT equipment, the test procedure and the applied interpretation formulae are to be found in the DMT 2001 Report by ISSMGE TC16 (2001). A comprehensive update of the above DMT Report, including information on its development in the last 15 years, has recently been published by Marchetti (2015a, b). References concerning DMT can be downloaded from www.marchetti-dmt.it.

Original correlations for determining geotechnical parameters developed by Marchetti (1980) are in part site-specific and of local character. In original correlations, constrained modulus $(M)$ depends on the dilatometer modulus $\left(E_{D}\right)$ with a variable coefficient $\left(R_{M}\right)$ depending on material index $\left(I_{D}\right)$ and horizontal stress index $\left(K_{D}\right)$. For the evaluation of undrained shear strength from DMT, Marchetti (1980) developed a correlation based on the relationship between normalized undrained shear strength $\left(\tau_{f u}\right)$ and overconsolidation ratio $(O C R)$ proposed by Ladd et al. (1977), and correlation of $O C R$ and $K_{D}$.

Comprehensive investigations were made to assess and enlarge the application of DMT in geotechnical engineering (Lutenegger 1988, Powell and Uglow 1988, Lunne et al. 1989, 2006, Monaco and Marchetti 2004, Schnaid 2009, Cao et al. 2015, Robertson 2015, Silvestri 
and Tabib 2015, Młynarek et al. 2016). However, in most relationships used to evaluate constrained modulus (Briaud and Miran 1991) and undrained shear strength, intermediate parameters $I_{D}, K_{D}$ and $E_{D}$ obtained from the DMT readings were commonly used. Roque et al. (1988) proposed an alternative approach for estimating undrained shear strength based on the correlation using $p_{1}$ readings and bearing capacity factor $\left(N_{c}\right)$. Different approaches were proposed by $\mathrm{Yu}$ et al. (1993) and Smith and Houlsby (1995), in which undrained shear strength was a function of the $p_{o}$ reading and the bearing capacity factor $\left(N_{D}\right)$. Multi-factor correlations were proposed by Rabarijoely (2000) to evaluate undrained shear strength $\left(\tau_{f u}\right)$, and by Ozer et al. (2006) to evaluate constrained modulus $(M)$.

This paper presents the results of dilatometer tests and laboratory tests of heavily overconsolidated boulder clays and Pliocene clays prevailing in the War- saw region. The problem of evaluating undrained shear strength and constrained modulus from dilatometer tests for heavily overconsolidated clays is discussed. Empirical coefficients for multi-factor correlations to obtain undrained shear strength for boulder clays as well as Pliocene clays are determined. The relationship between $R_{M}$ factor and horizontal stress index for boulder clays is proposed for the evaluation of constrained modulus from dilatometer tests.

\section{DESCRIPTION OF THE TEST SITE}

The test site was the II subway line in Warsaw, for which hydrogeological and geotechnical documentation was elaborated by the "Geoteko-WULS-Geoprojekt" Consortium. In 2003-2004, site investigation was carried out for the II subway line comprising 24 stations, 2 standstill stations and 24 tunnels, and in 2009 for

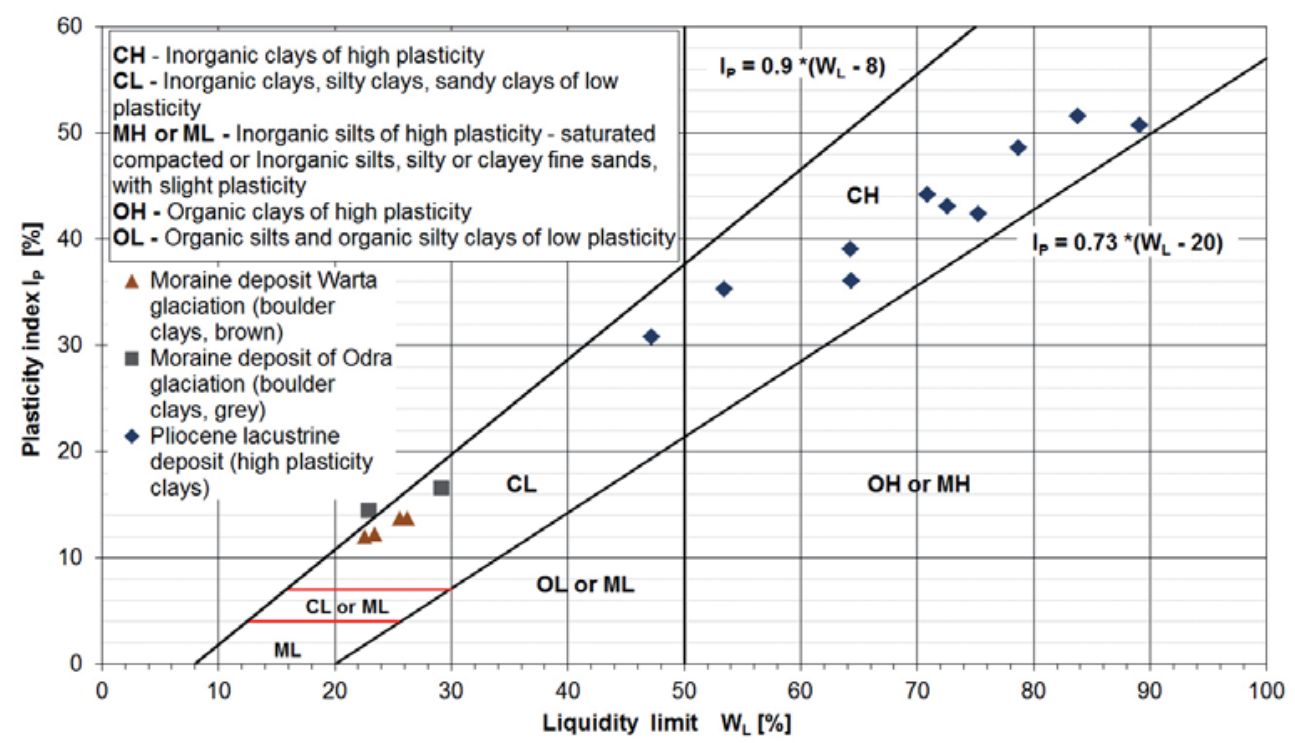

FIGURE 1. Tested soils from the II subway line in Warsaw on Casagrande's plasticity chart 
the II subway line following changes of the planned route, and comprising 20 stations, 2 standstill stations and 20 tunnels. Most of the results of field and laboratory tests shown in this paper are related to the subway stations located in the central part of the II subway line.

In general, the tested subsoil with the exception of surface anthropogenic fill consists of moraine deposits underlain by preglacial deposits or Pliocene clays. Analysis of field and laboratory test results has indicated that the tested soils can be classified as stiff brown boulder clays of the Warta Glaciation and grey boulder clays of the Odra Glaciation in the upper Quaternary layers, and stiff Pliocene clays in the lower Tertiary layer. Glacial moraine deposits of the Warta and Odra glaciations can be classified as low plasticity clays, and the Pliocene clays as high plasticity clays (Fig. 1). Grain-size distribution of the tested soils is shown in Figure 2. According to Standard EN ISO 14688-1:2002, the boulder clays can be classified as sandy clays (saCL), silty sandy clays (sasiCL) and clayey sands (clSa). Pliocene clays can be classified

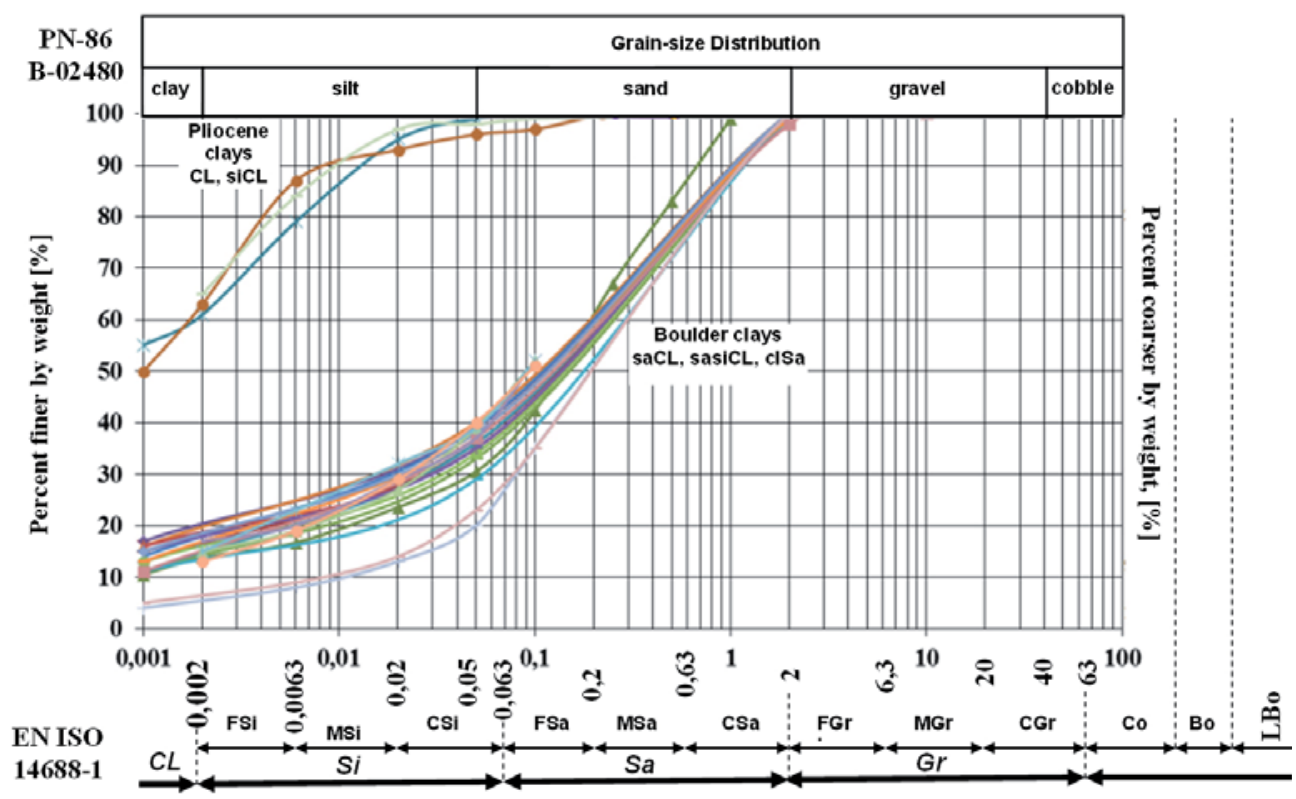

FIGURE 2. Typical grain-size distribution of the tested soils

TABLE. Index properties of the tested soils from the II subway line in Warsaw

\begin{tabular}{|l|c|c|c|c|}
\hline Properties & $\begin{array}{c}\text { Boulder clay } \\
\text { (brown) }\end{array}$ & $\begin{array}{c}\text { Boulder clay } \\
\text { (grey) }\end{array}$ & Pliocene clay & $\begin{array}{c}\text { Pliocene } \\
\text { silty clay }\end{array}$ \\
\hline Water content, $w_{n}(\%)$ & $10-14$ & $10-14$ & $18-25$ & $14-20$ \\
\hline Unit density, $\rho\left(\mathrm{t} \cdot \mathrm{m}^{-3}\right)$ & $2.1-2.2$ & $2.1-2.2$ & $1.9-2.0$ & $2.0-2.10$ \\
\hline Plasticity index, $I_{P}(\%)$ & $10-18$ & $10-18$ & $19-64$ & $23-48$ \\
\hline Liquidity index, $I_{L}(-)$ & $0.0-0.20$ & $0.0-0.20$ & $-0.10-0.15$ & $-0.10-0.10$ \\
\hline
\end{tabular}


as clays (CL) and silty clays (siCL). The index properties of the tested soils are shown in the Table.

\section{RESULTS OF DMT}

Profiles of $p_{o}$ and $p_{1}$ pressures and index parameters $I_{D}, K_{D}$ and $E_{D}$ from DMT carried out at the C11 Swiętokrzyska station for brown and grey sandy clays, and for Pliocene clay are shown in Figure 3 . In the case of the index parameters $I_{D}, K_{D}$ and $E_{D}$, the measured values with the average values and \pm one standard deviation are shown in Figure 3. Results of DMT shown in Figure 4 on Marchetti and Crapps chart (1981)

\section{EVALUATION OF UNDRAINED SHEAR STRENGTH}

Many studies have been performed to evaluate and improve some of the original correlations proposed by Marchetti (1980), however, new correlations are likewise mostly limited to mineral soils (Briaud and Mirian 1991).

The following correlation between normalized undrained shear strength and lateral stress index was proposed by Marchetti (1980) for cohesive soils $\left(I_{D}<1.2\right)$ :

$$
\frac{\tau_{f u}}{\sigma_{v o}^{\prime}}=0,22\left(0.5 \cdot K_{D}\right)^{1.25}
$$

where:

$\sigma_{v o}^{\prime}-$ in situ effective vertical stress.
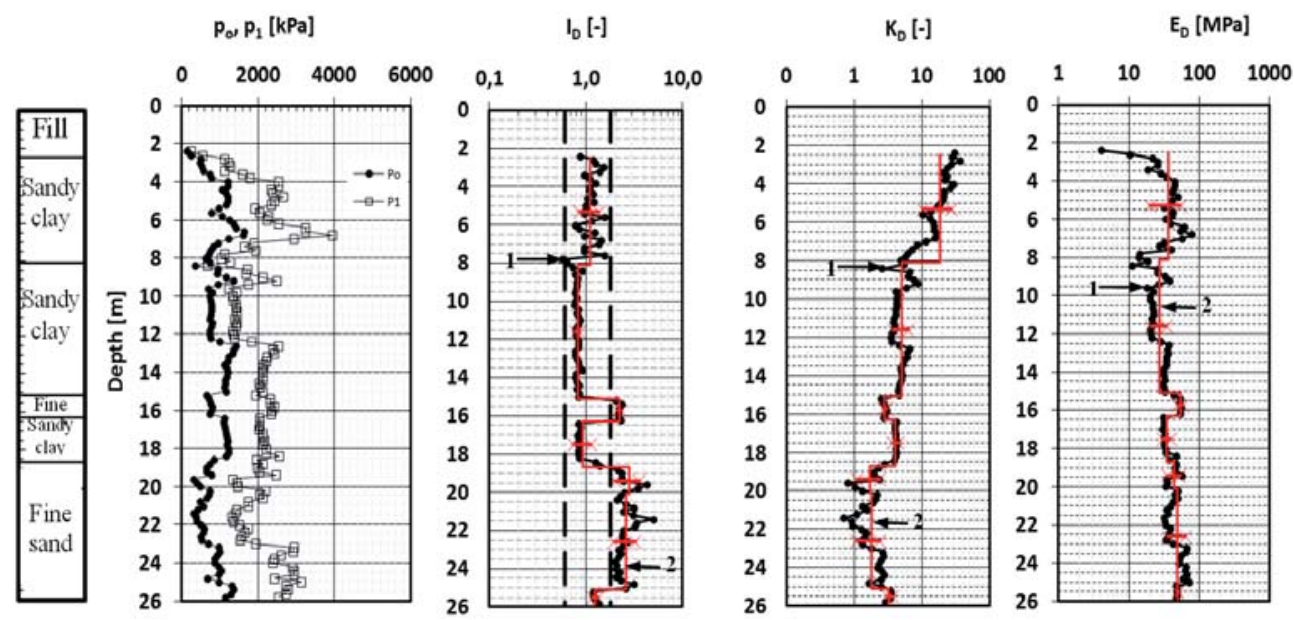

FIGURE 3. Profiles of $p_{o}$ and $p_{1}$ pressures and index parameters $I_{D}, K_{D}$ and $E_{D}$ from DMT: 1 - measured values, 2 - average values \pm one standard deviation

indicate that the tested soils are highly overconsolidated clays.
The analysis carried out by Smith and Houlsby (1995) indicates that undrained 


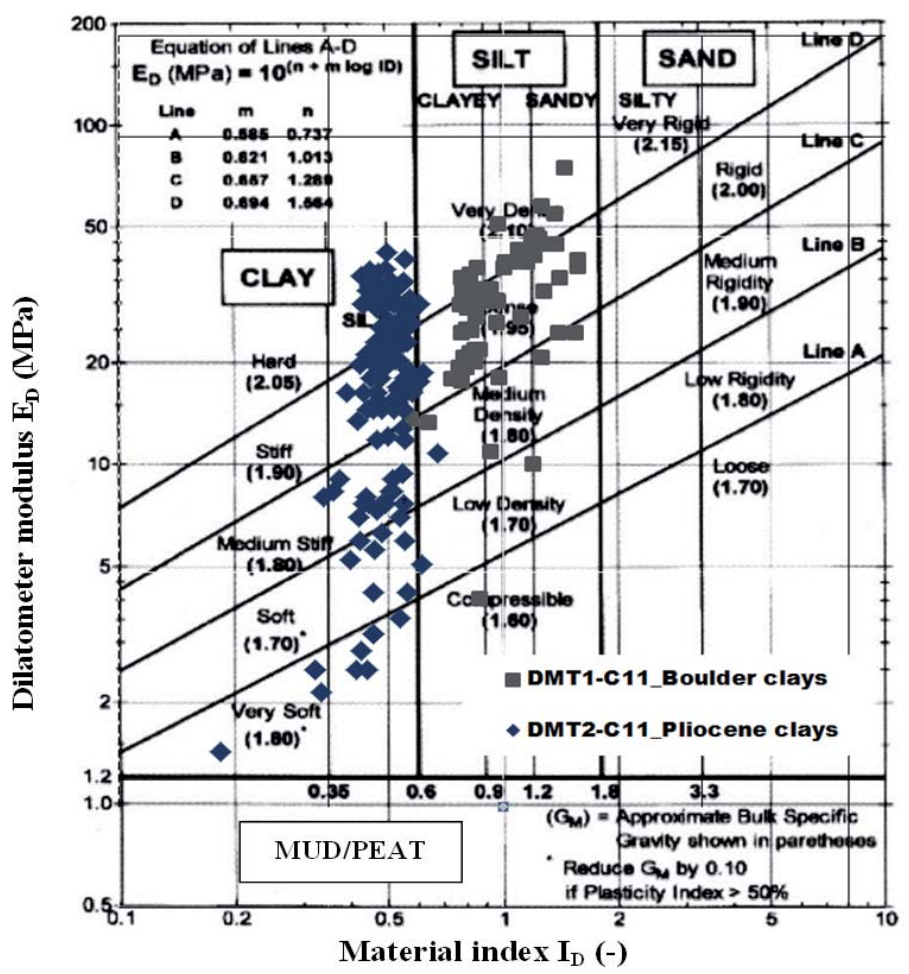

FIGURE 4. Tested soils shown on Marchetti and Crapps chart

shear strength can be estimated from the following formula:

$$
\tau_{f u}=\frac{p_{o}-\sigma_{h o}}{N_{D}}
$$

where:

$p_{o}$ - corrected first pressure reading; $N_{D}$ - dilatometer factor for clays, varying from about 4 to 7 .

In order to evaluate undrained shear strength in cohesive soils and its variability with depth, comprehensive investigations were undertaken by the Department of Geotechnical Engineering of the Warsaw University of Life Sciences - SGGW (WULS-SGGW). Undrained shear strength was determined in the laboratory in triaxial tests on undisturbed samples. In laboratory tests for samples taken from the tested area, a criterion for acceptable volumetric strain for the reconsolidation to in situ effective stress was used to determine the quality of the tested soil specimens.

Analysis of DMT results indicates that, particularly for boulder clays, the relationship between normalized undrained shear strength and horizontal stress index $\left(K_{D}\right)$ differs from that proposed by Marchetti in 1980 (Fig. 5).

The following modified correlation between normalised undrained shear strength and horizontal stress index for boulder clay is proposed (Fig. 5):

$$
\frac{\tau_{f u}}{\sigma_{v o}^{\prime}}=0.22 \cdot\left(0.5 \cdot K_{D}\right)^{1.12}
$$




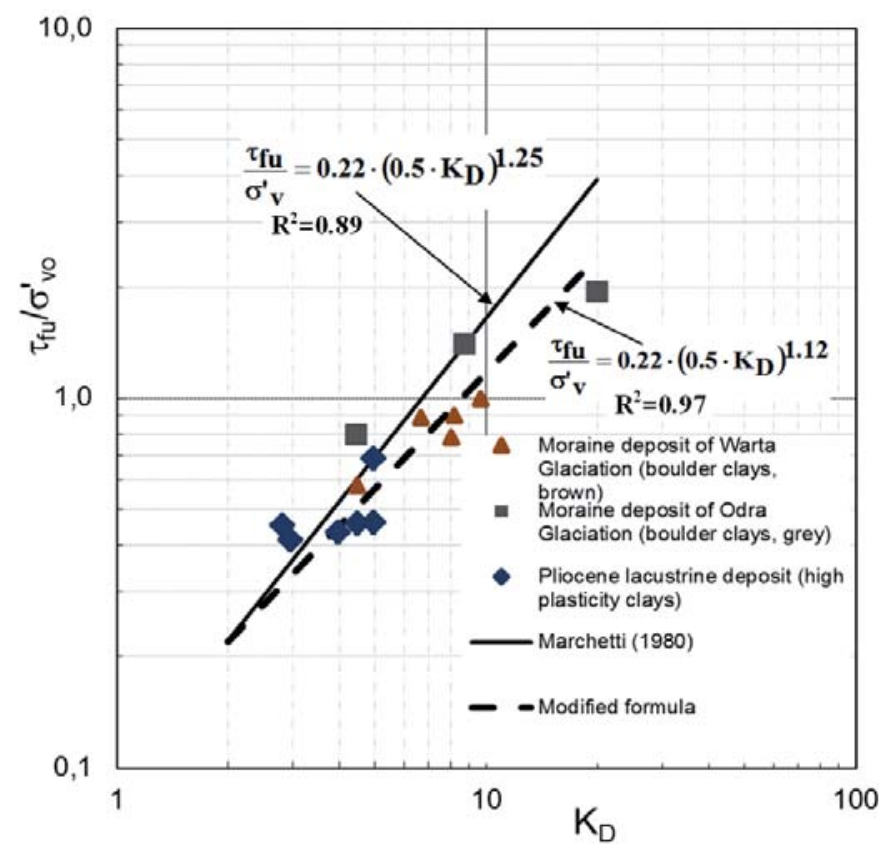

FIGURE 5. Relationship between normalized undrained shear strength $\left(\tau_{f u}\right)$ and horizontal stress index $\left(K_{D}\right)$
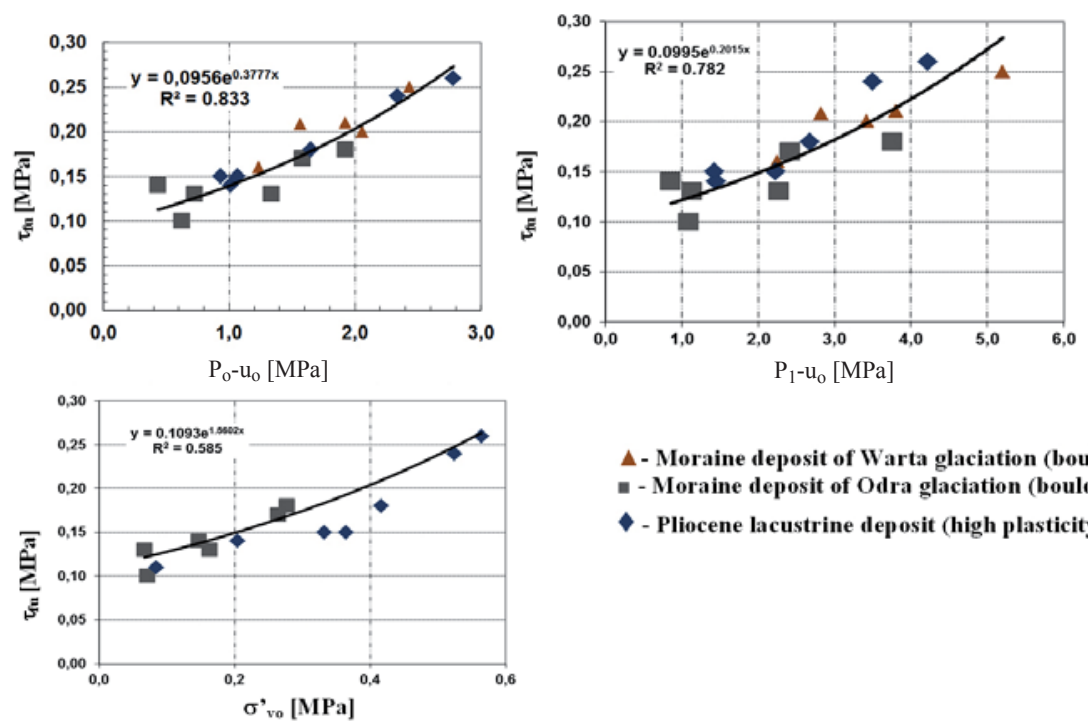

$\Delta$ - Moraine deposit of Warta glaciation (boulder clays - brown)

- Moraine deposit of Odra glaciation (boulder clays -grey)

$\checkmark$ - Pliocene lacustrine deposit (high plasticity clays)

FIGURE 6. Undrained shear strength $\left(\tau_{f u}\right)$ versus $p_{1}-u_{o}, p_{o}-u_{o}$ and $\sigma^{\prime}{ }_{v o}$ 
In Figure 6, undrained shear strength is correlated with different factors (difference between $p_{o}$ and $u_{o}$; difference between $p_{1}$ and $u_{o}$; effective vertical stress) similarly as in Rabarijoely (2000) and Ozer et al. (2006). Multiple regression analysis indicates quite good correlation, however a considerably lower $R^{2}$ value was obtained for the relationship between undrained shear strength and effective vertical stress.

Experience from organic soils indicates that for the evaluation of undrained shear strength from dilatometer tests, the following formula proposed by Rabarijoely (2000) can be used:

$$
\tau_{f u}=\alpha_{o}{\sigma_{v}^{\prime} \alpha_{1}}^{\prime}\left(p_{o}-u_{o}\right)^{\alpha_{2}} \cdot\left(p_{1}-u_{o}\right)^{\alpha_{3}}
$$

where:

$\sigma^{\prime}{ }_{v}$ - effective vertical stress;

$u_{o}$ - in situ pore water pressure;

$\alpha_{0}, \alpha_{1}, \alpha_{2}, \alpha_{3}$-empirical coefficients.

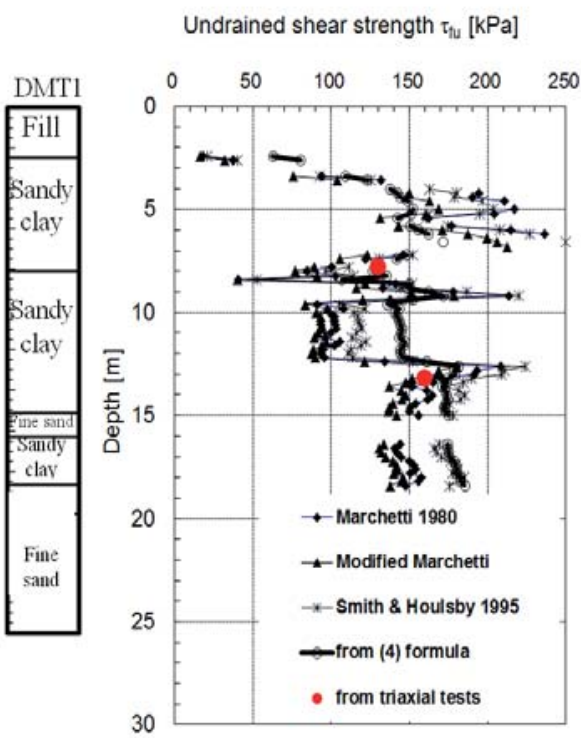

Analysis of test results indicates that the obtained values of empirical coefficients for formula (4) for boulder clays and Pliocene clays from the Warsaw region are $\alpha_{0}=0.18, \alpha_{1}=0.14, \alpha_{2}=0.20$, and $\alpha_{3}=0.15$.

In order to evaluate undrained shear strength from dilatometer tests, formula (4) with obtained values of empirical coefficients was used. A comparison between undrained shear strength obtained from triaxial tests and dilatometer tests for boulder clays and Pliocene clays from the Warsaw region is shown in Figure 7. In general, there is a good agreement between the evaluated undrained shear strength based on the multifactor relation and values obtained from triaxial tests.

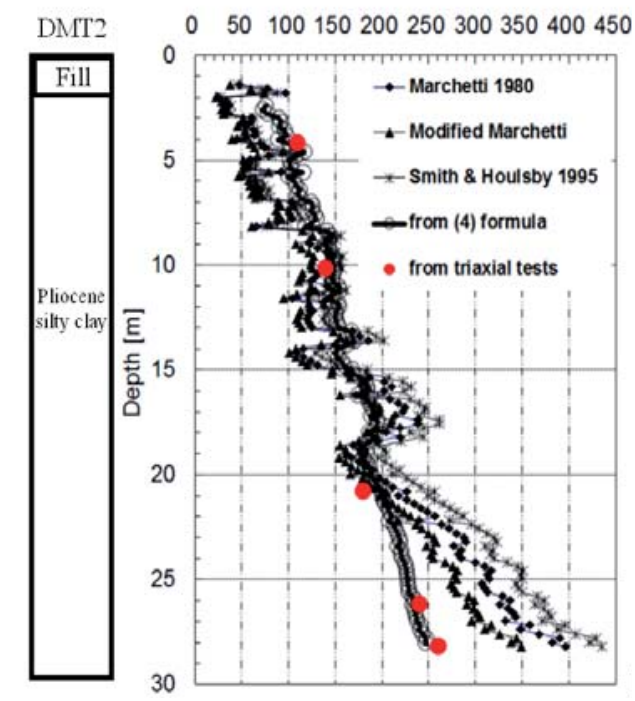

FIGURE 7. Profiles of undrained shear strength $\left(\tau_{f u}\right)$ 


\section{EVALUATION OF CONSTRAINED MODULUS}

In order to evaluate constrained modulus from dilatometer tests, the empirical correlations proposed by Marchetti (1980) are as follows:

$$
\begin{gathered}
M=R_{M} \cdot E_{D} \\
I_{D} \leq 0.6 \\
R_{M}=0.14+2.36 \cdot \log K_{D} \\
0.6<I_{D}<3.0 \\
R_{M}=0.14+0.36 \cdot\left(\frac{I_{D}-0.6}{2.4}\right)+ \\
+\left[2.5-\left(0.14+0.36 \cdot \frac{I_{D}-0.6}{2.4}\right)\right] \cdot \log K_{D}
\end{gathered}
$$

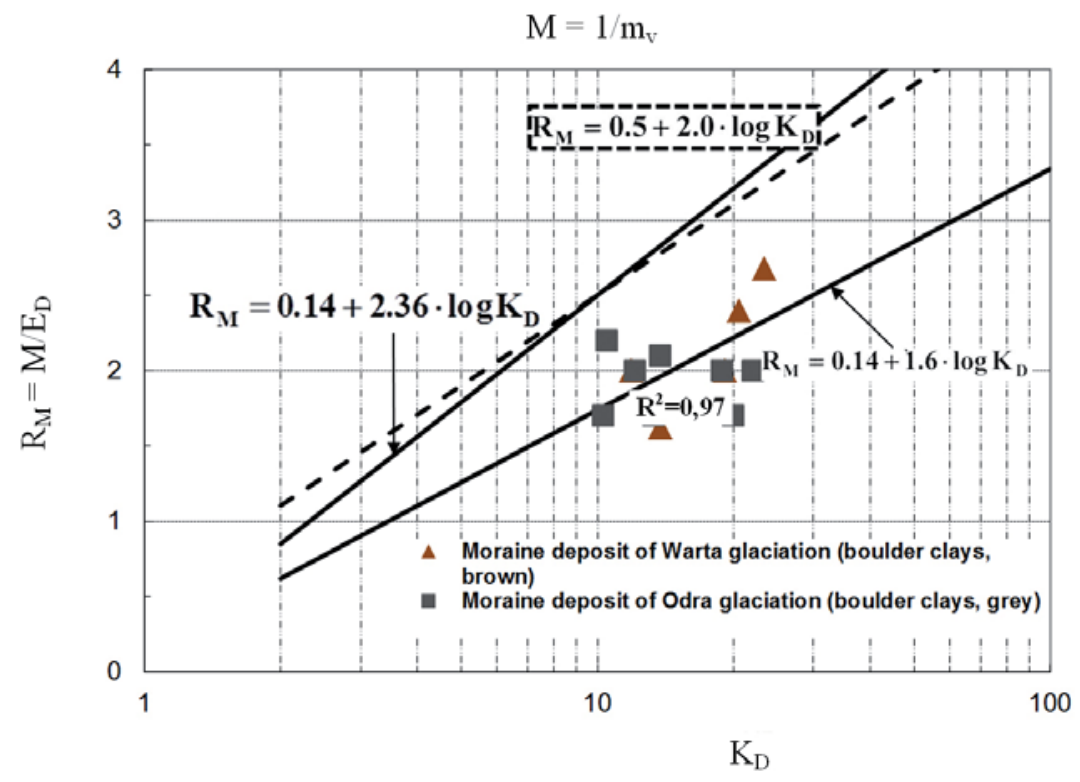

FIGURE 8. Factor $R_{M}=M / E_{D}$ versus $K_{D}$ where:

$R_{M}$ - factor related to horizontal stress in$\operatorname{dex}-K_{D}(-)$;

$E_{D}$ - dilatometer modulus (MPa);

$I_{D}$ - material index (-).

Analysis of DMT results and oedometer tests shows that for boulder clays the relationship between factor $R_{M}$ and index $K_{D}$ differs from that proposed by Marchetti in 1980 (Fig. 8). Comparison of the constrained modulus obtained from oedometer tests during reloading indicates that for interpretation of dilatometer tests in boulder clays, the following relation can be used for determination of the factor $R_{M}$ :

$$
R_{M}=0.14+1.6 \cdot \log K_{D}
$$




\section{CONCLUSIONS}

The paper presents the problem of accuracy in evaluating undrained shear strength and constrained modulus of heavily overconsolidated cohesive soils from dilatometer tests. A comparison between undrained shear strength from dilatometer tests evaluated from formulae presented in literature and undrained shear strength obtained from triaxial tests indicates significant differences. Empirical coefficients for boulder clays and Pliocene clays were determined for multi-factor correlation proposed by Rabarijoely (2000) used to obtain undrained shear strength from dilatometer tests. Analysis of DMT results and oedometer tests shows that for boulder clays the relationship between factor $R_{M}$ and index $K_{D}$ differs from that proposed by Marchetti (1980). The relationship between factor $R_{M}$ and index $K_{D}$ for boulder clays was proposed for evaluation of $M$ from dilatometer tests.

\section{REFERENCES}

ASTM D6635-01 2001, 2007: Standard test method for performing the flat plate dilatometer. Book of Standards.

BRIAUD J.L., MIRAN J. 1991: The flat dilatometer test. Civil Engineering Department, Texas A\&M University for Federal Highway Administration. Publ. FHWA-SA-91-044.

CAO L., CHANG M. F., TEH C.I. 2015: Analysis of dilatometer test in clay. Proc. $3^{\text {rd }}$ Int. Conf. on the Flat Dilatometer DMT'15, Roma, Italy, 385-392.

Eurocode 7 1997, 2007: Geotechnical Design - Part 2: Ground investigation and testing, EN 1997-2.
ISO 14688-1:2004: Geotechnical investigation and testing - Identification and classification of soil - Part 1: Identification and description.

ISO 14688-2:2004: Geotechnical investigation and testing - Identification and classification of soil - Part 2: Principles for a classification.

LADD C.C., FOOTT R., ISHIHARA K., SCHLOSSER F., POULOS H.G. 1977: Stress-deformation and strength characteristics. Proc. $10^{\text {th }}$ Int. Conf. on Soil Mech. and Found. Eng., Tokyo, 2, 421-494

LUNNE T., LACASSE S., RAD N.S. 1989: SPT, CPT, pressuremeter testing and recent developments on in situ testing of soils, Part I: All tests except SPT. Proc. $12^{\text {th }}$ ICSMFE, Rio de Janeiro, Session 2. Vol. 4, 2339-2403.

LUTENEGGER A.J. 1988: Current status of the Marchetti dilatometer test. Special Lecture. Proc. Int. Sym. on Penetration Testing (ISOPT-1), Orlando, 1, 137-155.

LUTENEGGER A.J. 2006: Cavity expansion model to estimate undrained shear strength in soft clay from dilatometer. Proc. $2^{\text {nd }}$ Int. Flat Dilatometer Conf., Washington, 319-326.

MARCHETTI S. 1980: In situ tests by flat dilatometer. J. Geotech. Eng. Div., ASCE 106, GT3, 299-321.

MARCHETTI S. 2015a: Some 2015 Updates to the TC16 DMT Report 2001. Proc. $3^{\text {rd }}$ Int. Conf. on the Flat Dilatometer DMT'15, Roma, Italy, 43-65.

MARCHETTI S. 2015b: Flat dilatometer (DMT). Applications and recent developments. Proc. Ind. Geotech. Conf., Pune, India,

MARCHETTI S., CRAPPS D.K. 1981: Flat dilatometer manual. Internal report of GPE.

MŁYNAREK Z., WIERZBICKI J., LUNNE T. 2016: On the influence of overconsolidation effect on the compressibility assessment of subsoil by means of CPTU and DMT. Ann. Warsaw Univ. of Life Sci. - SGGW, Land Reclam. 48 (3), 189-200. 
MONACO P., MARCHETTI S. 2004: Evaluation of the coefficient of subgrade reaction for design of multi-propped diaphragm walls from DMT moduli. Proc. ISC-2 on Geotech. and Geophys. Site Charact., 993-1002.

OZER A.T., BARTLETT S.F., LAWTON E.C. 2006: DMT testing for consolidation properties of the Lake Bonneville Clay. Proc. $2^{\text {nd }}$ Int. Flat Dilatometer Conference, Washington, 154-161.

POWELL J.J.M., UGLOW I.M. 1988: Marchetti dilatometer testing in UK soils. Proc. Int. Sym. on Penetration Testing (ISOPT-1), Orlando, 1, 555-562.

RABARIJOELY S. 2000: The use of dilatometer test for evaluation of organic soil parameters. Ph.D. thesis. Wydawnictwo SGGW, Warszawa [in Polish].

ROBERTSON P.K. 2015: Soil behavior type using the DMT. Proc. $3^{\text {rd }}$ Int. Flat Dilatometer Conf., Roma, Italy, 243-250.

ROQUE R., JANBU N., SENNESET K. 1988: Basic interpretation procedures of flat dilatometer tests. Proc. Int. Sym. on Penetration Testing ISOPT-1, Orlando, 1, 577-587.

SILVESTRI V., TABIB C. 2015: Application of the MCC model for the estimation of undrained geotechnical parameters of clays from dilatometer tests. Proc. $3^{\text {rd }}$ Int. Conf. on the Flat Dilatometer DMT'15, Roma, Italy, 431-438.

SCHNAID F. 2009. In situ testing in Geomechanics - the main tests. Taylor and Francis Group, London. TC16 2001: The flat dilatometer test (DMT) in soil investigations. A Report by the ISSMGE Committee TC16. May 2001. Reprinted in Proc. $2^{\text {nd }}$ Int. Conf. on the Flat Dilatometer, Washington D.C., 7-48.

SMITH M.G., HOULSBY G.T. 1995: Interpretation of the Marchetti dilatometer in clay. Proc. $11^{\text {th }}$ Eur. Conf. on Soil Mech. and Found. Eng. Vol. 1. Kopenhaga.

YU H.S., CARTER J.P., BOOKER J.R. 1993: Analysis of the dilatometer test in undrained clay. In: Predictive Soil Mechanics. Thomas Telford, London, 783-795.
Streszczenie: Wyznaczenie wytrzymałości na ścinanie bez odplywu i modulu ściśliwości z badań DMT silnie prekonsolidowanych iłów. W artykule przedstawiono wyniki badań dylatometrycznych i badań laboratoryjnych silnie prekonsolidowanych morenowych gruntów spoistych zlodowacenia Warty i Odry oraz iłów plioceńskich występujących na trasie II linii metra w Warszawie. Przedstawiono porównanie wartości wytrzymałości na ścinanie bez odpływu $\left(\tau_{f u}\right)$ badanych gruntów spoistych uzyskanych z badań dylatometrycznych, wykorzystując prezentowane w literaturze zależności empirycznych $\mathrm{z}$ wartościami wyznaczonymi z badań trójosiowych. Analiza wyników badań pozwoliła na określenie wartości współczynników empirycznych do wieloczynnikowej zależności zaproponowanej przez Rabarijoely'ego w 2000 roku, służącej wyznaczeniu wytrzymałości na ścinanie bez odpływu na podstawie badań dylatometrycznych. Porównanie wyników badań dylatometrycznych z wynikami badań edometrycznych wskazuje na istotne różnice między uzyskanymi wynikami a zależnością podaną przez Marchettiego w 1980 roku. Dla morenowych gruntów spoistych zlodowacenia Warty i Odry podano zależność empiryczną między wskaźnikiem $R_{M}$ a wskaźnikiem naprężenia bocznego $\left(K_{D}\right)$ wykorzystywaną w wyznaczeniu z badań dylatometrycznych modułu ściśliwości $(M)$.

\section{MS received June 2017}

\section{Authors' addresses:}

Zbigniew Lechowicz, Simon Rabarijoely

Katedra Geoinżynierii

Wydział Budownictwa i Inżynierii Środowiska SGGW

ul. Nowoursynowska 159, 02-776 Warszawa

Poland

e-mail: zbigniew_lechowicz@sggw.pl simon_rabarijoely@sggw.pl

Tetiana Kutia

Department of Applied Mathematics

National University of Water and Environmental Engineering

11 Soborna Str., 33028 Rivne

Ukraine

e-mail:kutetiana@gmail.com 